\title{
Arthroscopic Decompression in Subacromial Impingement Syndrome: An Overview of Our Outcomes
}

\author{
Subakromiyal Sıkışma Sendromunda Artroskopik Dekompresyon \\ Sonuçlarımız
}

(1) Vahit Yıldız' (1) Ömer Selim Yıldırım²

${ }^{1}$ Aydın Adnan Menderes University Faculty of Medicine, Department of Orthopedics and Traumatology, Aydın, Turkey

${ }^{2}$ Atatürk University Faculty of Medicine, Department of Orthopedics and Traumatology, Erzurum, Turkey

Keywords

Arthroscopic decompression, subacromial impingement, Surgery

Anahtar Kelimeler

Artroskopik dekompresyon, Subakromial sıkışma, Cerrahi

Received/Geliş Tarihi : 25.10 .2018

Accepted/Kabul Tarihi : 06.12.2018

doi:10.4274/meandros.galenos.2018.42650

Address for Correspondence/Yazışma Adresi: Vahit Yıldız MD,

Aydın Adnan Menderes University Faculty of Medicine, Department of Orthopedics and

Traumatology, Aydın, Turkey

Phone : +90 5052932783

E-mail :dr.vyildiz44@hotmail.com

ORCID ID: orcid.org/0000-0003-3639-0912

(C) Meandros Medical and Dental Journal, Published by Galenos Publishing House.

This is article distributed under the terms of the Creative Commons Attribution NonCommercial 4.0 International Licence (CC BY-NC 4.0).

\begin{abstract}
Objective: Subacromial Impingement syndrome (SIS) is a common cause of shoulder pain due to compression of rotator cuff muscles. We aimed to compare preoperative and postoperative functional and radiological features after arthroscopic decompression in patients with SIS.

Materials and Methods: Forty patients (22 male/18 female) with mean age of 49 (21-76) undergone arthroscopic decompression for SIS. The mean follow-up length was 12 months. Before and after the surgery functional and radiological evaluations were performed. Constant shoulder scoring technique was used for evaluating the shoulder functions. The subacromial distance was measured on the sagittal magnetic resonance imaging sections. In addition, preoperative and postoperative Constant shoulder scores of 15 (37.5\%) patients with a history of preoperative trauma and $14(35 \%)$ patients with chronic disease were compared separately with the other patients.

Results: Neer and Hawkins tests were positive in 39 (97.5\%) patients preoperatively and only $2(5 \%)$ patients had positive results postoperatively. The median score of the preoperative subacromial distance was 9.3 (8.6-9.8) while the median score was $10.9(9.9-11.8)$ in the postoperative measurements. The preoperative median value of the Constant shoulder score in all the patients was $11.5(5-21)$ and the postoperative median value was $80(61.25-85.5)$. While $36(90 \%)$ patients had night-time pain preoperatively, no patients had postoperatively. These values were significantly decreased after surgery $(p<0.001)$. Preoperative postoperative Constant shoulder scores of 15 (37.5\%) patients going through preoperative trauma and 14 (35\%) patients with chronic disease were not significantly different compared to the other patients.

Conclusion: Arthroscopic decompression is effective and safe in the treatment of stage 2 and 3 SIS. The subacromial distance should be recognized as an important criterion while managing SIS. Previous history of a chronic disease or trauma does not affect the outcome of the treatment in the patients suffering from SIS.
\end{abstract}

Öz

Amaç: Rotator cuff kaslarının sıkışmasına bağlı oluşan Subakromial Sıkışma sendromu (SSS) omuz ağrısının sık sebeplerindendir. Biz fonksiyonel ve radyolojik açıdan SSS nedeniyle artroskopik dekompresyon cerrahisi öncesi ve sonrası bulguları karşılaştırılmasını amaçladık. 
Gereç ve Yöntemler: SSS nedeniyle artroskopik dekompresyon yapılan ortalama yaşı 49 (21-76) olan 40 (22 Erkek/18 Kadın) hasta çalışmaya dahil edildi. Ortalama takip süresi 12 ay idi. Ameliyat öncesi ve sonrası fonksiyonel ve radyolojik açıdan değerlendirme yapıldı. Omuz fonksiyonlarını değerlendirmede Constant omuz skorlaması kullanıldı. Omuz sagittal manyetik rezonans görüntüleme kesitlerinden her iki omuzda subakromiyal mesafe ölçüldü. Ayrıca preoperatif travma öyküsü olan $15(\% 37,5)$ ve kronik hastalığı olan $14(\% 35)$ hastanın preoperatif ve postoperatif costant omuz skorları diğer hastalarla ayrı ayrı karşılaştırıldı.

Bulgular: Preoperatif $39(\% 97,5)$ hastada Neer ve Hawkins testi pozitifken, ameliyat sonrası $2(\% 5)$ hastada pozitif olarak saptandı. Preoperatif subakromiyal mesafe medyan değeri $9,3(8,6-9,8)$, postoperatif ölçümlerde ise medyan değer 10,9 $(9,9-11,8)$ idi. Constant omuz skoru tüm hastalarda preoperatif medyan değeri 11,5 (5-21), postoperatif medyan değeri $80(61,2-85,5)$ olarak ölçüldü. Preoperatif $36(\% 90)$ hastada gece ağrıları var iken postoperatif hiçbir hastada gece ağrısı görülmedi. Preoperatif ve postoperatif tüm bu değerler birbirleriyle karşılaştıııldığında istatistiksel olarak anlamlı olduğu görüldü $(p<0,001)$. Preoperatif travmaya maruz kalan $15(\% 37,5)$, kronik hastalığı olan $14(\% 35)$ hastanın preoperatif postoperatif costant omuz skorları diğer hastalarla karşılaştırıldığında anlamlı bir fark görülmedi.

Sonuç: Evre 2-3 SSS'nin tedavisinde artroskopik dekompresyon etkin ve güvenilirdir. SSS yönetiminde subakromiyal mesafe ölçümü önemli bir kriter olarak kabul edilmelidir. SSS'li hastada kronik hastalığın olması ve ameliyat öncesi travmaya maruz kalmış olması tedavi sonucunu etkilememektedir.

\section{Introduction}

One of the frequent causes of shoulder pain is the Subacromial Impingement syndrome (SIS), resulting from the compression of the rotator cuff with the acromion, the coracoacromial ligament, the coracoid process, and the acromioclavicular joint during the glenohumeral joint movements, especially during flexion and rotation (1). SIS is associated with various degenerative changes occurring in the coracoacromial ligament, the anterior part of the inferior surface of the acromion, and sometimes in the acromioclavicular joint. While vascular, degenerative, traumatic, and mechanical factors are involved in the aetiology of SIS, it is caused mostly by repeated traumas, poor perfusion, or degenerative changes due to strenuous movements exerted with occupational or sports purposes (2). The vascular factors are encountered more commonly with the increasing age; however, mechanical factors are seen in association with the acromial types and spur formation beneath the acromion. None of these etiologic factors can explain the underlying pathologic mechanisms exclusively but it is suggested that various interactive combinations of these four factors, the vascular, degenerative, traumatic, and mechanic ones, lead to the development of SIS.

The diagnosis of SIS can be made by the clinical findings and by the radiograms and magnetic resonance imaging (MRI). The most frequently observed clinical finding in SIS is pain often localized in the anterior shoulder. The pain exacerbates during the night and sometimes it is felt in the neck. The elevation of the arm is very painful especially in the range from 60 to
120 degrees. This finding is called as "Painful Arc". The pain is exacerbated by various activities including swimming, lifting the arm over the head, lifting heavy objects, driving, and throwing objects. The impingement test, lidocaine injection anterolateral to the acromion, is very important in the differential diagnosis. Neer and Hawkins test results are usually positive in these patients. Radiology is a key tool in the diagnosis of SIS. Regardless of the stage of the SIS, the following parameters are evaluated including the subacromial distance, the coracohumeral distance, the size of the hypertrophy in the acromioclavicular joint, the acromial type, and the discrepancies in the height of the centre of the humerus and that of the centre of the glenoid. A diagnosis of SIS will be likely if the subacromial length and the length of the shaft of the humerus are shorter than $7 \mathrm{~mm}$ and $12 \mathrm{~mm}$ respectively and if acromial types 2 or 3 are detected (3). Currently, the most sensitive, specific, and valid method in making the diagnosis of shoulder lesions is MRI. The pathological findings leading to the development of SIS can be detected with MRI including the supraspinatus tendinitis, a partial tear in the supraspinatus muscle, full thickness tears of the rotator cuff, and the hypertrophy of the acromioclavicular joint (Figure 1,2).

Neer described three pathological stages of SIS, which are treated either by conservative methods or by surgical interventions. The treatment is conservative in stage 1 , which is characterized by oedema and haemorrhage. Stage 2 is characterized by fibrosis and tendinitis is treated with conservative methods primarily. A surgical intervention is indicated for the 
patients with stage 2 SIS if they are unresponsive to the conservative treatment given up to 18 months. Stage 3 is characterised with the changes in the bones and ruptures of the tendons and treated by surgery (4). Arthroscopic decompression has recently been the most preferred method for the treatment of SIS as it is relatively less invasive and less costly, allowing for a faster recovery with a less likelihood for developing complications.

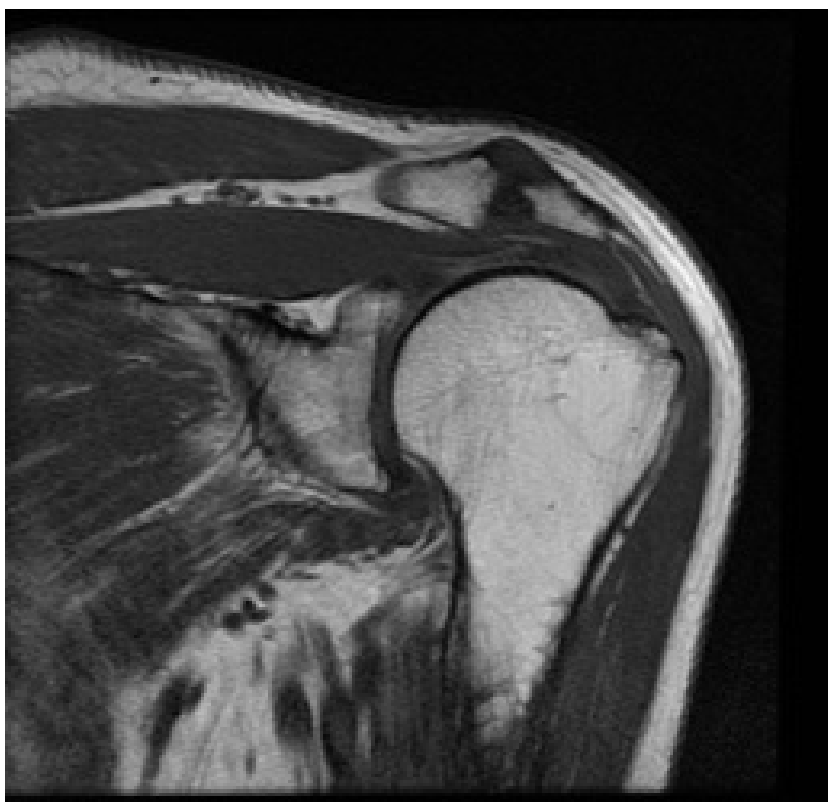

Figure 1. Acromioclavicular joint hypertrophy

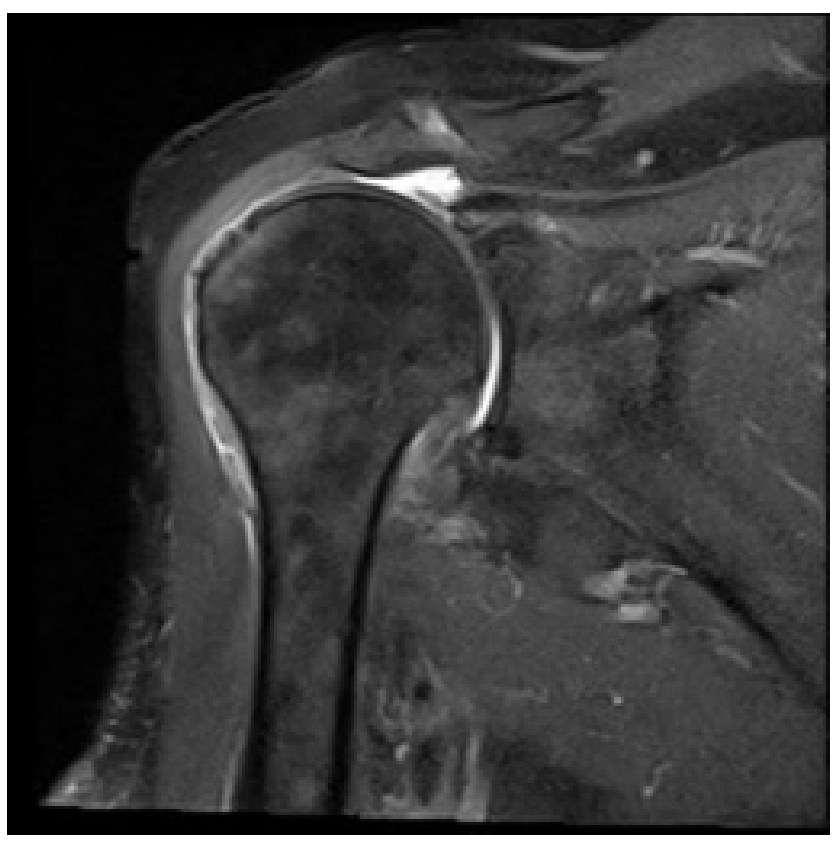

Figure 2. A full-thickness tear of the supraspinatus muscl

\section{Materials and Methods}

This study was aprroved by the Atatürk University Institutional Review Board (decision date and no: 12.06.2009-5/195). All volunteer patients included in this study were verbally informed about the study protocol and they signed the informed consent form.

Presenting to Atatürk University Faculty of Medicine, Department of Orthopedics and Traumatology between 2006 and 2010, a total of 40 patients with stage 2 and 3 SIS not responding to conservative treatment were included in the study. Of these patients, 22 (55\%) were women and 18 $(45 \%)$ were men with a mean age of 49 (21-76). In all patients, a thorough examination of the shoulder and Neer and Hawkins test along with the radiograms and $\mathrm{MRI}$ were performed in the preoperative period. Constant shoulder scoring technique was used for evaluation of the shoulder functions. The subacromial distance was measured in both shoulders in the sagittal sections of MRI. The study patients were categorized into trauma and chronic diseases subgroups according to their medical histories to be further evaluated. Arthroscopic decompression was applied to all patients in beach-chair position by the same surgical staff. General anaesthesia was applied in $4(10 \%)$ patients while 36 (90\%) patients were applied an interscalene block. A velpau bandage was applied to the patients with a hospital stay over 2.5 days. The exercises for physical rehabilitation started on the postoperative $4^{\text {th }}$ day. Postoperative Constant shoulder scores and subacromial distances of the patients with a mean follow-up of 12 months were measured and compared with the preoperative measurements. Following the reapplication of Hawkins and Neer tests during the last follow-ups, patients having night-time pain were detected and compared with preoperative values. Postoperative preoperative Constant scores of patients exposed to trauma and having any chronic disease were compared with the scores of other patients.

\section{Statistical Analysis}

The conformity of continuous variables to normal distribution was examined by using Shapiro-Wilk test. Descriptive statistics were shown as median (25$75 \%$ ) because none of the variables showed normal distribution. The Mann-Whitney $U$ test was used to compare the preoperative-postoperative Constant 
shoulder scores of the patients who were exposed to trauma and those with chronic disease with the other groups. Wilcoxon T test was used to compare preoperative postoperative Constant shoulder scores and subacromial distances. Descriptive statistics of categorical variables were shown as numbers (\%). Preoperative postoperative Hawkins, Neer test and Mc. Nemar test was used to compare night-time pain.

\section{Results}

The median preoperative Constant shoulder score was measured as 11.5 (5.0-21.0); and the median postoperative as $80.0(61.5-85.0) \quad(p<0.001)$. The median score of the preoperative subacromial distance measurement was 9.3 (8.6-9.8) and the postoperative median score was 10.9 (9.9-11.8) $(p<0.001)$ (Table 1$)$.

Thirty-six (90\%) preoperative patients had nighttime pain; however, no night-time pain was observed in any postoperative patient. Neer and Hawkins test scores were found to be positive in 39 (97.5\%)

\begin{tabular}{|l|l|l|l|}
\hline $\begin{array}{l}\text { Table 1. Comparison of preoperative postoperative } \\
\text { Constant score }\end{array}$ \\
\hline $\begin{array}{l}\text { Preoperative } \\
\text { median score }\end{array}$ & $\begin{array}{l}\text { Postoperative } \\
\text { median score }\end{array}$ & $\mathbf{p}$ \\
\hline Constant & $11.5(5-21)$ & $80(61.25-85.5)$ & $<0.001$ \\
\hline $\begin{array}{l}\text { Subacromial } \\
\text { distance }\end{array}$ & $9.3(8.6-9.8)$ & $10.9(9.9-11.8)$ & $<0.001$ \\
\hline
\end{tabular}

Table 2. The relation between trauma and preoperative postoperative Constant scores

\begin{tabular}{|l|l|l|l|} 
& $\begin{array}{l}\text { The patients } \\
\text { going through } \\
\text { a trauma }\end{array}$ & $\begin{array}{l}\text { The patients } \\
\text { not going } \\
\text { through a } \\
\text { trauma }\end{array}$ & $\mathbf{p}$ \\
\hline Preop Constant & $8(4-18)$ & $12(5.5-27.5)$ & 0.361 \\
\hline Postop Constant & $74(58-86)$ & $81(61.5-86)$ & 0.600 \\
\hline
\end{tabular}

Table 3. The relation between chronic diseases and preoperative postoperative Constant scores

\begin{tabular}{|l|l|l|l|}
\hline & $\begin{array}{l}\text { The patients } \\
\text { with chronic } \\
\text { disease }\end{array}$ & $\begin{array}{l}\text { The patients } \\
\text { not having any } \\
\text { chronic disease }\end{array}$ & $\mathbf{p}$ \\
\hline $\begin{array}{l}\text { Preop } \\
\text { Constant }\end{array}$ & $7.5(3.7-18.75)$ & $12(5.7-27.7)$ & 0.380 \\
\hline $\begin{array}{l}\text { Postop } \\
\text { Constant }\end{array}$ & $73(57.2-86.2)$ & $81(61.7-84)$ & 0.552 \\
\hline
\end{tabular}

preoperative patients; however, they were observed to be positive in only $2(5 \%)$ postoperative patients. A statistically significant difference was observed when comparing these scores with each other $(p<0.001)$. Thirty-six (90\%) preoperative patients had night-time pain; however, no night-time pain was observed in any postoperative patient. When all the preoperative and postoperative Constant scores were compared, it was found to be statistically significant $(p<0.001)$.

The median preoperative Constant score was 8 (4-18) in the patients going through a trauma and 12 (5.5-27.5) in patients not going through a trauma $(p=0.361)$. The median postoperative Constant score was 74 (58-86) in the patients going through a trauma and 81 (61.5-86) in patients not going through a trauma $(p=0.600)$ (Table 2$)$.

The median preoperative Constant score was 7.5 (3.7-18.7) in the patients with chronic disease and 12 (5.7-27.7) $(p=0.380)$ in the patients not having any chronic disease. The median postoperative Constant score was 73 (57.2-86.2) in the patients with chronic disease and $81(61.7-84)(p=0.552)$ in the patients not having any chronic disease (Table 3 ).

After treatment, 8 (20\%) patients had biceps tendinitis, $2(5 \%)$ had triceps tendinitis, and $4(10 \%)$ had transient neuropraxia. Steroid injection was applied to the patients with biceps tendinitis at the $3^{\text {rd }}$ month follow-up. No complication was observed in the patients undergoing 8 weeks of follow-up.

\section{Discussion}

It was described by Codman for the first time that the emergent changes in the supraspinatus tendon caused subacromial bursitis $(5,6)$. In his study in 1972, Neer popularized the term "impingement", suggesting that $95 \%$ of the rotator cuff tears were associated with the impingement phenomenon (7). Several studies conducted later also supported this hypothesis (8-10).

Several factors are involved in the aetiology of SIS, including the vascular, degenerative, traumatic, and mechanical ones. The vascular factors cause SIS increasingly more with the increasing age. The mechanical factors are associated with the acromial types and spur formation beneath the acromion. SIS was associated mostly with trauma in the patients younger than 55 years of age in our study. In our study patients older than 55 years, the hypertrophy of the acromioclavicular joint and the thickenings due 
to spur formation in the inferior acromion were most common. In their study, Karabulut M. (11) reported that the major triggering causes of SIS were trauma and repetitive movements in $37.5 \%$ and $22.5 \%$ of the patients respectively, however, no triggering events were identified in $40 \%$ of the patients. Trauma was the triggering factor in 15 (37.5\%) patients in our study. The parameters of the patients in whom trauma was the triggering factor were not statistically different compared to those in the other patient subgroups. The association of the chronic diseases with SIS is controversial. Morisson suggested that the response rates obtained in the patients with chronic diseases were relatively low, however, Conroy observed no differences in the patients in terms of the treatment response (12). Our study found that 14 (30\%) patients suffered from chronic diseases, the most common ones being hypertension and diabetes respectively. The data collected from these patients were not statistically different from the other patients in the study.

Neer and Post report that in SIS, otherwise known as "Painful Arc syndrome", the pain is aggravated by movements (especially abduction and internal rotation) and especially during the night (13). The patients included in our study had complaints of a neck pain, a restricted range of motions in the shoulder, and pain during the night. These complaints were dramatically improved after the intervention. SIS was diagnosed in two patients treated with physical therapy due to a diagnosis of a cervical hernia and the pain was relieved also in these patients after the operation. We concluded that persistent neck pain should be thoroughly investigated in the physical therapy patient to exclude a potential diagnosis of SIS.

The primary treatment is conservative in the patients with stage 1 and 2 SIS. Ellman H. (14) reported successful results with relative resting, antiinflammatory medications, physical therapy, rotator cuff strengthening exercises in stage 2 SIS.

Surgery is indicated in stage 3 patients and stage 2 patients who do not respond to the conservative treatment applied over a period of 18 months (4). Subacromial decompression has been recognised as a successful mode of surgical treatment in chronic SIS patients. Arthroscopic subacromial decompression has become a common method used in shoulder surgeries as arthroscopy is less invasive and has a less likelihood of leading to complications (15).
Arthroscopic methods have started to be used by the end of the 1980s in subacromial decompression $(16,17)$. Currently, arthroscopic acromioplasty is increasingly being used for the surgical treatment of the impingement syndrome. It is reported that the superiorities of arthroscopic acromioplasty over open surgeries become evident especially in the early postoperative period. In the literature, several studies report that arthroscopic surgery methods are superior to open surgery in the short-term as demonstrated by the alleviation of pain after the surgery, shorter length of hospital stay, and a shorter period of time required to go back to work. However, no differences were observed in the intensity of pain, the range of motion, and the muscle strength in the long-term (18).

Spangehl et al. (19) evaluated both techniques in their study and reported that the University of California at Los Angeles and patient satisfaction scores were similar after both open surgery techniques and arthroscopic surgeries. However, they reported that the results were more successful after the open surgeries in terms of the functionality and the reduction in the pain intensity. A proportion of reviews in the literature reported that similar results were obtained by both of these techniques, including the subjective and objective outcomes in the short and long term (19). In the view of these contradictory results in the literature, we have concluded that arthroscopic surgery is advantageous in evaluating intra-articular pathologies and the method is associated with a smaller scar size, however, it does not provide superior results in the long term compared to open surgeries.

Neer and Hawkins tests are highly important in making a diagnosis of SIS. In his study, Çalış et al. (20) showed that the most sensitive test was Hawkins with a sensitivity of $92.1 \%$, followed by Neer with a sensitivity of $88.7 \%$ in making the diagnosis of SIS. In our study, Neer and Hawkins tests showed specificity rates of $98 \%$ consistent with being the most sensitive tests in making the diagnosis of SIS as reported in the literature.

The mean Constant score was 15 preoperatively, however, they were improved and found to be 72 after the surgery. The outcomes observed in every study patient was almost outstanding consistent with the literature. The preoperative and postoperative results were statistically significantly different. 
The subacromial distance was measured using radiological means in our study. Prior to the surgery, the mean subacromial distance was approximately $10.3 \mathrm{~mm}$ in the intact shoulder and $9.3 \mathrm{~mm}$ in the damaged shoulder. After the operation, it increased to a mean of $10.9 \mathrm{~mm}$ approximately. The shorter subacromial distance in the diseased shoulder before the surgery, compared to the intact one, can be explained with the following factors including the diminished depressing strength of the supraspinatus muscle, the intra-articular narrowing caused by the inactivity due to pain, the presence of osteoarthrosis in the older age patients, and the emergent hypertrophic spurs in the acromioclavicular joint. Subacromial decompression and debridement, as well as the application of pressurized water into the intra-articular space during the arthroscopy cause significant increases in these distances. The current study suggests that a subacromial distance less than $9.3 \mathrm{~mm}$ can be recognized as an important criterion in making the diagnosis of SIS.

Shoulder arthroscopy is becoming increasingly common today and the success of this procedure will be likely if potential complications are avoided. Neurologic complications are among the most frequent complications with rates ranging between 0 and $30 \%$ (21). They may emerge depending on the way of entry, occurring as traction injuries, or they may develop according to the position of the patient (22). The involved peripheral nerves may include the axillary nerve, median nerve, radial nerve, ulnar nerve, and the musculocutaneous nerve (21). Many of these injuries occur in the form of neurapraxia and almost all of them resolve over time. Nerve injuries may develop during the placement of the portals if optimal care is not exercised. Another common complication during shoulder arthroscopy is the emergent increased compartment pressure due to the leakage of lavage fluid out of the joint capsule into the surrounding tissues. Ogilvie-Harris and Boynton performed arthroscopic acromioplasties in 25 patients and reported that the mean pressure on the deltoid muscle was $27 \mathrm{mmHg}$ and $72 \mathrm{mmHg}$ during the glenohumeral arthroscopy and subacromial arthroscopy respectively. They added that the pressure returned to the normal levels in the $4^{\text {th }}$ minute after the arthroscopy although the oedema in the muscle persisted further. The authors found normal results in the electromyography in the postoperative $4^{\text {th }}$ and $6^{\text {th }}$ weeks (23). The studies conducted by Lee et al. (24) also support these results. The rates of infection after the shoulder arthroscopy is quite low and most centres do not use prophylactic antibiotics at all. The rates of infection have been reported in the range from $0.04 \%$ to $0.23 \%$ in large series (25). latrogenic cartilage injuries are not occasional, which may develop accidentally during the placement of the portals. However, long term outcomes of these injuries have not been reported. The relatively rare complications of shoulder arthroscopy may include deep vein thrombosis, subcutaneous emphysema, pneumomediastinum, and pneumothorax. In our study, some complications developed in the study patients, too, including biceps tendinitis in $8(10 \%)$ patients, triceps tendinitis in $2(5 \%)$ patients and neuropraxia in $4(10 \%)$ patients. Corticosteroids injections were made in 2 patients with biceps tendinitis. The complications did not persist in any of the patients as observed in the $8^{\text {th }}$ week follow-up visits after physical therapy.

\section{Conclusion}

The subacromial distance should be recognised as an important criterion in the diagnosis of SIS and should be compared to that of the opposite shoulder. In patients with Stage 3 SIS and Stage 2 SIS who do not respond to the conservative treatment modalities, the arthroscopic subacromial decompression have been suggested to be an effective treatment option in recent years, in terms of reducing the pain, returning to the daily activities of living, and increasing the range of motion in the shoulder. The following factors in the medical histories of the patients with SIS, including chronic diseases and previous traumas does not affect the outcome of the treatment. As a result of this study, it has been determined that when used in combination with the support of functional and radiological data of the respective patients, the arthroscopic subacromial decompression surgery is an effective method for the treatment of SIS.

\section{Ethics}

Ethics Committee Approval: This study was aprroved by the Atatürk University Institutional Review Board (decision date and no: 12.06.20095/195). 
Informed Consent: All volunteer patients included in this study were verbally informed about the study protocol and they signed the informed consent form.

Peer-rewiev: Externally and internally peerreviewed.

\section{Authorship Contributions}

Surgical and Medical Practices: V.Y., Ö.S.Y., Concept: V.Y., Ö.S.Y., Design: V.Y., Ö.S.Y., Data Collection or Processing: V.Y., Analysis or Interpretation: V.Y., Ö.S.Y., Literature Search: V.Y., Writing: V.Y.

Conflict of Interest: No conflict of interest has been reported by the authors.

Financial Disclosure: The authors reported that they did not receive financial support.

\section{References}

1. Matsen FA, Arntz CT. Subacromial Impingement. In: Rockwood C.A, 1990; 2: 5-15.

2. Greenfield B, Catlin PA, Coats PW, Green E, McDonald JJ, North C. Posture in patients with shoulder overuse injuries and healthy individuals. J Orthop Sports Phys Ther 1995; 21: 287-95.

3. Cyprien JM, Vasey HM, Burdet A, Bonvin JC, Kritsikis N, Vuagnat P. Humeral retrotorsion and glenohumeral relationship in the normal shoulder and in recurrent anterior dislocation. Clin Orthop Relat Res 1983; 175: 8-17.

4. Neer CS 2nd. Impingement lesions. Clin Orthop Relat Res 1983; 70-7.

5. Petterson G. Rupture of the tend aponeurosis of the shoulder joint antero-inferior dislocation. Acta C Scand (Suppl) 1942; 77: 1-187.

6. Rockwood CA. Surgical treatment of the shoulder impingement. A modification of the Neer anterior acromioplasty in 71 shoulders. Orthop Trans 1990; 14: 251.

7. Neer CS, Marberry TA. On the disadvantages of radical acromionectomy. J Bone Joint Surg Am 1981; 63: 416-9.

8. Frieman BG, Albert TJ, Fenlin JM Jr. Rotator cuff disease: a review of diagnosis, pathophysiology and current trends in treatment. Arch Phys Med Rehabil 1994; 75: 604-9.

9. Glousman RE. Instability versus impingement syndrome in the throwing athlete. Orthop Clin North Am 1993; 24: 89-99.

10. Wasilewski SA, Frankl U. Rotator cuff pathology. Artroscopic assesment and treatment. Clin Orthop Relat Res 1991; 267: 6570.
11. Karabulut M. Subakromiyal sıkışma sendromu konservatif tedavisinde lazerin etkinliğinin araştrılması. Uzmanlık tezi. İstanbul 2006.

12. Conroy DE, Hayes KW. TheEffect of Joint Mobilization as a Component of Comprehensive Treatment for Primary Shoulder Impingement Syndrome. J Orthop Sports Phys Ther 1998; 28: 3-14.

13. Post M, Cohen J. Impingement syndrome -A review of late stage II and early stage III lesions. Clin Orthop 1986; 207: 126-32.

14. Ellman $\mathrm{H}$. Arthroscopic subacromial decompression: analysis of one- to three-year results. Arthroscopy 1987; 3: 173-81.

15. Atalar AC, Demirhan M, Kocabey $Y$, Akalyn Y. Artroskopik subakromiyal dekompresyon: 1-7 yıllık sonuçlar. Acta Orthop Traumatol Turc 2001; 35: 377-81.

16. Ellman H, Kay SP, Wirth M. Arthroscopic treatment of full thickness rotator cuff tears: 2- to 7-year follow-up study. Arthroscopy1993; 9: 195-200.

17. Stephens SR, Warren RF, Payne LZ, Wickiewicz TL, Altchek D W. Arthroscopic acromioplasty: a 6- to 10-year follow-up. Arthroscopy 1998; 14: 382-8.

18. Bezer M, Aydin N, Erol B, Kocaoğlu B, Güven O. Late results of arthroscopic and open anterior acromioplasty. Acta Orthop Traumatol Turc 2004; 38: 115-9.

19. Spangehl MJ, Hawkins RH, McCormack RG, Loomer RL. Arthroscopic versus open acromioplasty: a prospective, randomized, blinded study. J Shoulder Elbow Surg 2002; 11: 101-7.

20. Caliş M, Akgün K, Birtane M, Karacan I, Caliş H, Tüzün F. Diagnostic values of clinical diagnostic tests in subacromial impingement syndrome. Ann Rheum Dis 2000; 59: 44-7.

21. Andrews JR, Carson WG Jr, Ortega K. Arthroscopy of the shoulder: techniqueand normal anatomy. Am J Sports Med 1984; 12: 1-7.

22. Rodeo SA, Forster RA, Weiland AJ. Neurological complications due to arthroscopy. J Bone Joint Surg Am 1993; 75: 917-26.

23. Ogilvie-Harris DJ, Boynton E. Arthroscopic acromioplasty: extravasation of fluid into the deltoid muscle. Arthroscopy 1990; 6: $52-4$.

24. Lee HC, Dewan N, Crosby L. Subcutaneous emphysema, pneumomediastinum and potentially life-threatening tension pneumothorax. Pulmonary complications from arthroscopic shoulder decompression. Chest. 1992; 101: 1265-7.

25. D'Angelo GL, Ogilvie-Harris DJ. Septic arthritis following arthroscopy withcost/benefit analysis of antibiotic prophylaxis. Arthroscopy 1988; 4: 10-4. 